\title{
BOUNDARIES: BOURGEOIS BELGIUM AND “TENTACULAR" MODERNISM
}

\author{
DEBORA L. SILVERMAN \\ Department of History and Art History, University of California, Los Angeles \\ E-mail: deborasilverman@gmail.com
}

Every science investigates phenomena that are homogenous and clearly distinguished from the problems of other sciences, whereas reality ignores boundaries and every section of the world presents an aggregate of tasks for all the sciences.

Georg Simmel, The Philosophy of Money

The sweep, originality, and plenitude of Jerrold Seigel's work have transformed our field. His prolific and creative scholarship encompasses the history of ideas, the history of cultural forms, and the history of intellectuals, areas typically examined separately as coherent and discrete sections of intellectual history. I have been reading Seigel for many years now, assigned his texts in my classes, and watched students come alive as they encounter his Marx, his Bohemia, his Baudelaire, his Foucault, his Simmel. My own research and writing have been deeply influenced by key ideas generated in Seigel's body of work, testing and contesting, for example, his project of historicizing subjectivity and identity in modern Europe.

Rereading four of Seigel's books spanning nearly four decades informs my article, requiring brief descriptions of them. First, after courageously veering from his training as a Renaissance specialist, Seigel produced Marx's Fate, a groundbreaking "psychological biography." He lifted to view Hegel's littleknown theory of the human life cycle, which closely resembled the stages of identity formation later defined by Erik Erikson. Seigel deftly mobilized these concepts to illuminate thematic patterns in Karl Marx's life and writings, offering a remarkable interpretation of Das Kapital and Marx's inability to finish it. Next, in Bohemian Paris, Seigel drew a group portrait of avant-garde figures in post-Revolutionary France to advance a pioneering argument: that Bohemia

Georg Simmel, The Philosophy of Money, trans. Tom Bottomore and David Frisby (London, 1990), 80-81. 
operated not as a world of opposition to the bourgeoisie, but as a necessary expression of it-an experimental no-man's-land dramatizing the ambivalence inherent in bourgeois notions of self-mastery and self-development. In The Idea of the Self, Seigel explored "thought and experience in Western Europe since the seventeenth century" by devising a bold framework and proposing original readings of masters of social thought in three national contexts. Finally, in Modernity and Bourgeois Life, Seigel reframed our understanding of Western European bourgeois modernity, recasting it less as a set of class relations than as a "form of life" organized around a "network of means" such as markets, states, and knowledge creation. Adapting Simmel's notion of "social tools," he emphasized fluidity, circulation, and extension across distances, a "thickening" of connective networks powered by physical, financial, and informational mobility.

Returning to these texts crystallized for me a number of consistent qualities in Seigel's work and his contributions to modern intellectual history. He practices the art of analytical history, enlisting wide-ranging evidence and sources for bold and persuasive arguments. He moves across disciplines, from philosophy and social theory to literature and the visual arts, unfolding close readings in multiple contexts. He positions himself squarely in the heart of Western Europe, demonstrating the complexity and generativity of scholarly projects that still await us there. He offers exemplary research and writing in comparative history, which few have the language skills, ambition, and erudition to pursue, and many brashly undervalue in the lure of the "transnational." He inflects his topics with psychological insights and categories, shaping splendid accounts of the interaction of personal, political, and intellectual history. He lifts to view the foundational commitment of the historian-change over time-in clear chronological frames and identifies "turning points" or "watershed" moments. These qualities of synthetic capacities and interpretive originality have led reviewers to use the term "magisterial" in their reviews of Seigel's books.

One consistent theme unifies these works: the emergence and condition of "free subjectivity" $(B P, 26)$, which Seigel also calls "liberated individuality." I see at the core of his many projects the aim to restore the drama, dilemmas, and achievements of the distinctively modern bourgeois individual. Michel Foucault dethroned individualism, rendering it a feature of one episteme among many; it surfaced briefly only to be erased, another fossil in the archaeology of knowledge and a tiny speck in the sands of time. Eric Hobsbawm gave center stage to the

Seigel draws on the first term from Hegel's writing on the French Revolution; he identifies the second in Jerrold Seigel, "Jerrold Seigel on the Ties between Modernity and Bourgeois Life in Western Europe" (interview), in fifteen eightyfour: Academic Perspectives from Cambridge University Press, 23 April 2012, at www.cambridgeblog.org/2012/04/ jerrold-seigel-on-the-ties-between-modernity-and-bourgeois-life-in-western-europe. 
European bourgeoisie and emphasized a new site and predicament of modern individuals in the family. As the nineteenth century divided home and office, production and reproduction, a central paradox reigned, Hobsbawm argued; the leveling atomization of the competitive marketplace in the outer world yielded the re-creation of feudal hierarchies in the private domain of the nuclear family. Here absolutist patriarchy and maternal devotion consolidated the domestic sphere as a "haven in a heartless world" while intensifying emotional bonds within it. Thus the enveloping comfort and order of the new bourgeois family vied with fears of dependency and pressures of expectation for children as they grew into adult individuals. ${ }^{3}$

In contrast to both Foucault and Hobsbawm, Seigel refocuses our attention on bourgeois subjectivity as an enduring historical breakthrough and unprecedented accomplishment. Indeed, his books cohere as a profound and extended meditation on the meaning and development of liberation for the modern individual. Echoing Marx and Simmel, Seigel emphasizes the rupture that loosened the grip of the corporate society of estates after the French Revolution, shifting anchorage from the local and the parochial to the equality of national citizens. And he reclaims as daunting, audacious, vexed, and protracted the ensuing process of self-creation in the nineteenth century, where modern subjects were now irrevocably bound to live as autonomous individuals. Marx's astonished admiration for the relentless dynamism of bourgeois innovation reverberates in some of Seigel's evocation of the energies and resources unleashed by a new industrial and political order. He rejects those historical interpreters who cast the European bourgeoisie as brazen, craven, and simian, burdened by the weight of Old Regime aristocratic cultures and caught in the vise of emulating them. Seigel's modern bourgeois as "liberated individuality" is more nuanced, and more inherently psychological. His model is rooted in the embrace of freedom and the attendant quandaries over freedom's limits and boundaries; he considers it overall ambivalent, yet exhilarating, a disposition braced to absorb the promises of expanded sensibility that modernity offered along with its terrors of isolation and dislocation. Here Baudelaire's painter of modern life and Simmel's metropolis dweller flow into the historical framework of Seigel's modernity and bourgeois life.

An ascending scale of analysis unfolds in Seigel's successive positions on bourgeois selfhood. Marx's Fate relies on a developmental model in time, where an individual passes through one stage of life to the next. A spatial marker and linear frontier organize Bohemian Paris. Seigel here builds an imaginary mapping, a psychological geography that divides the zone from bohemian to bourgeois. $\mathrm{He}$

3 Eric Hobsbawm, The Age of Empire (London, 1987), 165-91. 
shows us figures moving across, or back and forth, testing the borderline as they approach or retreat. When, in Modernity and Bourgeois Life, he turns to Simmel's idea of "networks of means," Seigel shifts conceptual gears: from stages in time to simultaneity, from linear divisions to clusters. In this book, Seigel highlights new forms of communication, transportation, and the circulation of money and ideas as they afford "thicker" connections and extensive linkages for self and society; they are multidirectional, and protean, where set boundaries give way and are continually made anew.

Simmel himself alighted on two images to convey these unprecedented qualities of the "thickening" and extensiveness of modern life: the wave and the thread. ${ }^{4}$ Enlarged horizons for the metropolitan individual, he wrote, comprised experience that is "extended in a wave-like motion over a broader national and international area." And Simmel compared the countless relations that keep increasing for the modern subject to endlessly multiplying threads: "From every thread which is spun out ... there continue, growing as out of themselves, an endless number of others." ${ }^{\text {"Th }}$ The encompassing sweep of the waves, the elongated and dense field of threads: these captured for Simmel the new breadth and extensiveness of modernity, the connectors and linkages that for Seigel's bourgeois world brought new groups together and the distance irrevocably nearer.

Whether as line, wave, or field, boundaries are central to Seigel's thought. He sets them in dynamic tension with the free subjectivity unleashed in the modern world. Though pliable and impermanent, boundaries are nonetheless required for both bourgeois and avant-garde, reemerging in new ways to offset modernity's form-dissolving flux. Here Baudelaire's embrace of disintegration and discipline provides Seigel with a quintessential figure. Taking "a bath of multitude," Baudelaire's artist luxuriates as "non-ego" where the ordinary citizen remains pitiably encased, like a mollusk in its shell. ${ }^{6}$ Yet yielding to the rush and shock of the new is not an end goal, but generates new rules: the artist adheres to a rigorous "code of laws" imposed on the self, and considers his form-giving powers as what Baudelaire termed "childhood recaptured at will," mobilizing the "analytical mind" essential to create order out of the pluralized flow and barrage of materials. ${ }^{7}$ Art encompasses, but constantly overcomes, boundarylessness as a

These are not commented on by Seigel, but they amplify his analysis and are central to my essay. They appear in Simmel's 1903 text "The Metropolis and Mental Life," in Georg Simmel on Individuality and Social Forms: Selected Writings, ed. and trans. Donald Levine (Chicago, 1971), 324-39.

5 Ibid., 335, 334.

6 Charles Baudelaire, “Crowds," in Baudelaire, Paris Spleen, trans. Louise Varèse (New York, 1970), 20.

7 Charles Baudelaire, “The Painter of Modern Life," in Baudelaire, Selected Writings about Art and Literature, ed. and trans. P. E. Charvet (London, 1972), 390-436, at 419, 398. 
condition of creativity; for Baudelaire, the work of art constructs, and veils, "the terrors of the eternal abyss." If he scoffs at the protective armor of the crustacean bourgeois, Baudelaire's veil nonetheless comprises a boundary, fragile and thin though it is, marking the division between chaos and expressive production.

\section{UNBOUNDED BOURGEOIS BELGIUM}

As Seigel knows well, not all bourgeoisies, or the artists that issued from them, are created equal. Indeed, his acute interpretive skills draw out different paths to modernity in nineteenth-century France, Germany, and England. But these explorations in the heart of Western Europe leave unattended other sites, and other constellations of self and society. In an earlier book on Vincent van Gogh, for example, I found in the nineteenth-century Netherlands an intact theological and corporate culture that erected powerful barriers to individualism. Autonomous, "free subjectivity" was impermissible, and even beyond the thinkable in Van Gogh's world, which was governed by what I called the "relational ego": a self composed only in and through association with others. ${ }^{9}$ In my current project on the avant-garde and the long nineteenth century in Belgium, I trace another set of striking contrasts with Seigel's model, lying at the other end of the spectrum from Dutch anti-egoism. In this context, boundaries, boundary breaking, and boundarylessness have particular and consequential historical meaning and resonance.

Undeservedly understudied, Belgium may have been, by 1860, the most liberal country in Europe and, arguably, the most bourgeois. By 1910, it was a center of global economic and technological power. Here, "liberated individuality" ruled supreme in a political structure of radical decentralization, a new and weak monarchy, fierce protection of local freedoms, and deep distrust of the state. In this distinctive historical setting, I identify startling patterns of what can be called "hyper-individualism," as well as disinhibition, evoked, for example, in the 188 os appeal to liberty, equality, and "contumacy"-a condition of staunch unruliness and intractable resistance to authority. ${ }^{10}$ The challenges of subjectivity and its limits that Seigel tracks do not reverberate here; rather than navigating

8 Charles Baudelaire, "A Heroic Death" in Baudelaire, Paris Spleen, 56.

9 Debora Silverman, Van Gogh and Gauguin: The Search for Sacred Art (New York, 200o), Introduction, chap. 5; and Silverman "Weaving Painting: Religious and Social Origins of Vincent van Gogh's Pictorial Labor," in Michael S. Roth, ed., Rediscovering History: Culture, Politics, and the Psyche (Stanford, 1994), 137-68.

10 This is from Georges Eekhoud's Nouvelle Carthage (Brussels, 2004; first published 1888), part 3, chap. 4, "Contumace," 313. Note how the root of the term is related to "tumescent," and defined in part as having "a swelled head" and marked by hubristic refusal to be subjugated. 
the borders of Bohemia at the margins of bourgeois life, as did the case of the French avant-garde, the members of the Belgian avant-garde in the 188 os were leaders of a new national culture in the process of formation, a project that allied bourgeois elites across the boundaries of politics, law, and the arts in a common quest for social reform and a unifying belgitude-where to locate the essence of identity in a new and artificial country.

Seigel's Western European focus also obscures a formidable "network of means," Belgian-style. Dense, and extensive, structures of communication, circulation, and mobility took shape in unmatched form in late nineteenthcentury Belgium, shorn of the centralizing state directives that managed them in France and Germany. Particularly innovative and versatile were the sectors of banking, engineering, and railway transportation, symbiotically connected and controlled by a small number of families of unbridled bourgeois, including the Solvays, the Stoclets, and the Empains - remarkable entrepreneurs who have yet to be adequately integrated into the narrative of European history. In 1900, the concentration and rampant reach of Belgian technology and the companies that grew up to fund them, for example, yielded the Paris Métro and railway lines, advisers, and matériel in China, Italy, Russia, Austria, Heliopolis (Egypt), and Brazil. All of these financial and technical combines flowed into the improbable and astonishingly lucrative venture initiated by King Leopold II and authorized by the Belgian parliament in 1885 to develop the resource-rich areas of the newly created Congo Free State. By 1895, the pliable borders of the king's domain had swelled to one million square miles, and the abundance of ivory and wild rubber to be found there created a surge of investment, exploration, and trade. Concession companies erupted in Brussels and Antwerp as decades of far-flung laissez-faire expansionism now linked a small buffer state in Europe to the jungles and waterways of Central Africa. The fluidity and unimpeded movement of capital, products, and people that characterized the Congo enterprise conformed in some ways to the energizing "social tools" and flows of money that Seigel adapted from Simmel $(B M L, 7)$. But the Belgian case consolidated a robust and rapacious form of modernity and imperial bourgeois life in the fin de siècle. Imperialism does not feature in Seigel's characterization of the resources and quandaries of the bourgeoisies that he studies. ${ }^{11}$

1 In Between Cultures, his most recent book, Seigel does seek to address the relationship between "Europe and its others." But Belgium's imperial economy and society had unique forms and functions, particularly as the Congo Free State through 1908 was not a colony but a conjury, a non-settler empire where products, in profusion, were primary, and not based on the interaction, however vexed, of subject peoples. I discuss these specific characteristics of Belgian imperialism and their impact in Belgium in my "Art Nouveau, 


\section{ÉMILE VERHAEREN'S TENTACULAR MODERNISM}

In the rest of my essay, I explore some literary expressions of the distinctively Belgian form of the two themes of Seigel's work-the boundaries of the bourgeoisie, and the modern "network of means"-by focusing on a single figure from my research, the avant-garde poet Émile Verhaeren (1855-1916). The Francocentric model of the avant-garde has unjustly deflected attention from this influential and important artist. While unfamiliar to us today, Verhaeren was, by 1910, a prolific, celebrated, national and international writer, a friend of Mallarmé's and Verlaine's and revered by many, including Stefan Zweig, Rilke, and Rodin. He came a close second to winning the 1911 Nobel Prize in Literature, which was claimed by his compatriot Maurice Maeterlinck. Like many of his avant-garde cohort in fin de siècle Belgium, Verhaeren combined symbolist innovation, political radicalism, and imperial enthrallment. As a symbolist, Verhaeren embraced the new form of free verse (vers libre) first championed by Mallarmé. But, as we shall see, he transposed the new style into a particularly Belgian key. An ardent socialist, Verhaeren broke the boundaries of the stanzaic frame to capture not the complex lineaments of the soul, but the dynamic cataclysm of industrial machines and impending revolution. Indeed, I will suggest that poems in Verhaeren's 1895 collection, Les villes tentaculaires (Tentacular Cities), offer the closest literary equivalent of Marx's vision of the wonders and creative destruction of bourgeois modernity, as well as its convulsive character: that "all that is solid melts into air." Furthermore, Verhaeren wielded his liberated literary techniques to express the boundary-breaking exhilaration of Belgium's imperial Congo. In his poems of Les villes and Les forces tumultueuses (Tumultuous Forces) (1902), Verhaeren, I will show, celebrates overseas expansionism and the port of Antwerp's voracious inflow of the globe's bounty.

My analysis will concentrate on two images from Verhaeren's oeuvre that illuminate affinities and some striking contrasts with Seigel's accounts of boundaries and bourgeois modernity. For Verhaeren, the unprecedented upheavals of modern industrialism and expansionism activated by Belgium's bourgeoisie found expressive form in this remarkable pair: tentacles and hands, reaching across the waves. Simmel, as we have seen, imagined modern life's connecting networks as a field of threads that grows thicker and denser, each one spawning another, endlessly. Verhaeren's vision casts modernity as irresistible tentacles that wrap, grip, and feed, draining the country to the industrial city's insatiable swell. And we recall Simmel's "wave-like motion," opening out to broader horizons and linking to distant areas. Verhaeren, too, identifies in his 
poetry the wave-like movements of modernity: his propel ships with outstretched, grasping hands. Simmel posits links as spun threads that grow out, organically, in a natural burst akin to dendrites or branches; Verhaeren's connectors are vampiric, portrayed as a many-tentacled warrior in an asymmetrical power grab. Simmel's wave toward the distance is an encompassing sweep, expansive; Verhaeren's is a forceful pulse, extractive. In this divergence between the textural and the tentacular, the moving wave as extending out or as surging back, loaded up with treasure, a dual character of liberated modernity emerges: one evoking Seigel's European bourgeoisies, vexed, but progressive, fortified by new energies and resources set free by self and social mastery; and one, closer to Conrad's world, the "armored cosmopolitanism" of imperial liberal expansion and domination. ${ }^{12}$ Verhaeren's career and poetry offer a unique avenue of entry into the exceptional and exemplary case that is Belgium's long nineteenth century, and the historically specific predicament of the bourgeois boundaries coursing through it.

\section{IN SEARCH OF BELGITUDE}

[Verhaeren] stood for Belgium in every part of her being. The world has never seen ... another poet who so truly embodied within himself the soul of a country. Flemish by birth and ancestry, Walloon, that is French, in mind and speech, he was indeed the twin-faced poet of this twin-headed people; yet his heart was single; and its singleness has been well proved..$^{13}$

Maurice Maeterlinck's characterization of Émile Verhaeren's single heart and double being captured the idealism coursing through Belgian modernism during the last two decades of the nineteenth century. With Verhaeren as one of its leaders, generational cohorts calling themselves Jeune Belgique sought to forge a unifying culture for their young nation. For a short, intense, and optimistic period, artists joined in a common quest and a paradoxical goal: to create a new Belgian culture based on resources from the Flemish past, presented in French, by largely French-speaking Flemish elites. Verhaeren and his comrades wielded the banner of "Soyons nous" ("Let us be ourselves"), celebrating their roles as second-stage liberators: where the work of "the founders" of 1830 had achieved political independence and economic development, it was now to the work of cultural emancipation that the generation of 1880 needed to turn.

Verhaeren's Young Belgium initiated a burst of national creativity that came to be known as La Belgique en Éveil, or "Belgium Rising." In fin de siècle France, as

12 Paul Gilroy, After Empire: Melancholia or Convivial Culture? (Abingdon, 2004), 66, 70.

13 Maurice Maeterlinck quoted in Amy Lowell, "Émile Verhaeren," in C. D. Warner, ed., The Library of the World's Best Literature, An Anthology in Thirty Volumes (New York, 1917), accessed at www.bartleby.com. 
both Seigel and I have written, avant-garde artists withdrew to smaller and smaller circles, alienated from the public world, and the symbolists aimed to liberate language from what they saw as the tawdry and corrupt quotidian reality of the Third Republic. Belgium in the 188os, by contrast, resembled France in the 1840 , the period of Romantic synthesis of artistic and social idealism. Empowered and engaged, Verhaeren and his cohort rallied to shape a new and distinctively Belgian modern style. When French writer Camille Mauclair visited Belgium in 1896, he was astonished at the range and effectiveness of intellectual power in a country that had suddenly become, as he grudgingly acknowledged, the creative "spiritual sister" to France. The accelerated "renaissance" of Belgian culture, Mauclair went on to note, showed an enviable state: "One hundred persons now form the taste of this country ... they show us that a vibrant and refined elite can legitimately prevail over the inertia of a people to activate a tradition of beauty." ${ }^{14}$ Let us see now how Émile Verhaeren, a pivotal figure in this cultural nation-building project, broke through the boundaries of literary form and national lethargy to devise a symbolist poetry embracing social radicalism and imperial enthusiasm.

At first glance, Verhaeren's early life took shape as did others in the mid-century European bourgeoisies: laced with parental pressure and high expectations. But these broad similarities give way to distinctive features of the Belgian setting. Born in 1855, Verhaeren was raised in the village of Sint-Amands near Antwerp, a mixed rural and semi-industrial area set on the bend of the Scheldt river. His father's family, originally Dutch, from Brussels, had run a successful draper's business; his mother's, of French descent, owned the retail cloth store in SintAmands. Retired from commerce when his son was born, Verhaeren père was a village notable and a Catholic church elder who took the boy to daily Mass. Only French was spoken at home, and it was the language of Verhaeren's upbringing.

As a youth Verhaeren learned some Flemish dialect playing with local children, but after a few years in the village school his parents sent him to Brussels for two years to polish his French and prepare for entry to the École Saint-Barbe, the elite Jesuit boarding school in Ghent. This institution, also attended by Maeterlinck and future poets Georges Rodenbach and Charles Van Lerberghe, gave Verhaeren a rigorous education in the classics and training in the demanding protocols of the French language, even while he and his new friend Rodenbach secretly read the prohibited texts of Hugo and Lamartine. On his return home in 1875 after graduating from Saint-Barbe, Verhaeren's proud parents set him to work in his prosperous uncle's local oil refinery works. There, he initially trained as an accountant. But Verhaeren had other inclinations, and he left the business and

14 Camille Mauclair, "La Belgique par un Français," La revue encyclopédique, 24 July 1897, 585. 
Sint-Amands to study law at the University of Louvain, completing his degree in 1881.

Louvain had sparked Verhaeren's literary ambitions, and he helped to start a student magazine there. He began in 1881 a three-year Brussels internship under Edmond Picard, a leading jurist and writer who was charged with systematizing Belgian law. The stage with Picard formed the turning point in Verhaeren's career. A novelist, art critic, and playwright, Picard presided over the law courts while acting as a mentor and magnet for young Belgian artists, many of whom, like Verhaeren, had trained as lawyers. The colossal new Palais de justice, opened in 1883 , provided the headquarters of the Jeune Barreau ("Young Bar"), where Picard and his group of young avocats-esthètes organized exhibitions and convened, in chambers, for the final lecture of the 1893 tour they sponsored for French symbolist poet Paul Verlaine. Picard founded and edited L'art moderne, a pioneering literary journal, and enlisted Verhaeren's contributions to its pages; Picard and fellow lawyer Octave Maus created the forum for a unitary avant-garde in the salons of Les XX after 1884. In this cauldron of modernist cultural activism, Verhaeren, with Picard's encouragement, gave up the legal profession and turned instead to art. $^{15}$

How to craft a culture of belgitude, uniting Flemish and Walloon, and to flow from a new country cobbled together from a patchwork of territories that had been ruled in the past by Spanish, Austrian, French, and Dutch masters? Verhaeren and his cohort landed on the Flemish art-historical past as building blocks for a new francophone literary canon. This invented tradition cohered as a dualism of idealization: at one end, the fifteenth-century mystical serenity of Jan Van Eyck and Hans Memling; at the other, the baroque corporeal exuberance of Peter Paul Rubens and Jacob Jordaens. Exploring these twin legacies of a modern "Belgian soul" (l'âme belge, in Picard's term) provoked Verhaeren's literary debut. The tension between them, and the impasse thus created for him, prepared the groundwork for his breakthrough to symbolist socialism.

In Les flamandes (1883), his first book of poems, Verhaeren celebrated the festive culture of bodily excess and indulgent conviviality he saw evoked in the paintings of Rubens, Teniers, and Jordaens. Verhaeren dedicated the book to Rubens's full-bodied women, whom he considered the embodiment of "l'idéal charnel

15 Gustave Vanwelkenhuysen, Vocations littéraires: Camille Lemonnier, Georges Eekhoud, Émile Verhaeren, Georges Rodenbach, Maurice Maeterlinck (Geneva, 1959); Robert Gilsoul, La théorie de l'art pour l'art chez les écrivains belges (Brussels, 1939); Jane Block, "The Art of the Law: Le Jeune Barreau, Patron of the Arts and Letters," in Block, ed., Belgium: The Golden Decades 1880-1914 (New York, 1997), 181-219; Debora Silverman, “'Modernité sans Frontières': Culture, Politics, and the Boundaries of the Avant-Garde in King Leopold's Belgium 1885-1910," American Imago 68/4 (2011), 707-97. 
flamand"-Flemish carnality. ${ }^{16}$ With poems on drink and peasant kermesses, the shape and gait of cows and pigs, and the special fleshy voluptuousness of Flemish women, Verhaeren's poems affirmed a type of exclamatory sensuality, devising inventive literary terms to capture the glow, sweat, pulse, and grease of folds of skin, a thick description of the world of gras, as Verhaeren named it - the bulky, viscous world of heavy and pleasured bodies. ${ }^{17}$ His family, his village, and conservative Catholics were scandalized; unfavorable critics labeled Verhaeren the poet a barbare. He embraced the epithet.

Part of the shock of the work was not only the scatological and erotic content of Les flamandes, but also its reliance on conventional form. Verhaeren's poems delighted in the tension between the formal propriety of the traditional French alexandrine frames he had mastered and the sensual and bestial depictions he inserted in them. Picard's review of it slyly called Verhaeren's work a tribute to "LARD POUR LARD"- "lard for lard," but also a play on "art for art's sake." Nonetheless Picard praised it as a revivification in modern form of the Flemish love of play and the senses, recaptured from the seventeenth century. ${ }^{18}$

Verhaeren followed this debut of tribute to corporeal revelry and libidinal excess with a retreat and extended stay in the Trappist monastery of Notre-Dame de Chimay, where he wrote a collection of poems on the ascetic severity and mystical exaltation of Les moines (Monks) (1886). That same period yielded a set of stories, one of which was called "Conte gras," with illustration by Théo Van Rysselberghe. Here the protagonist, Emil Vinck-thought by critics to be a stand-in for E.V., or Émile Verhaeren-experiences the confrontation and conflict of the two ends of the rediscovered Flemish dualism. In the print, E.V., the art collector of numerous Rubensian canvases of romping nudes, layered with glossy, resinous paint, sits and daydreams as he studies a new acquisition, a canvas of the Crucifixion. To his horror, M. Vinck beholds the encounter of the spirit and the sins of the flesh, and the spirit wins: the story recounts, as the image reveals as well, the melting and dissolution of the bodies in the Rubensian world, relegated to oily drips on the mantle that fall onto an open book and the floor below it. The seated E.V. gazes, immobilized, caught between the melting materiality of

16 Émile Verhaeren, “Aux flamandes d'autrefois," from Verhaeren, Les flamandes (1883), in Paul Gorceix, ed., Fin de siècle et symbolisme en Belgique: Oeuvres poétiques (Brussels, 1998), 165.

17 Albert Giraud, "Les flamandes," La Jeune Belgique 2 (1882-3), 109-15, at 110.

18 Albert Giraud, "Les moines, à Émile Verhaeren," La Jeune Belgique 5 (1885-6), 303-9, at 304; see also discussion of the review and the book in Gilsoul, La théorie de l'art, 142-3. 
pleasure behind him and the irradiated blast of sacred light and suffering bodies before him. ${ }^{19}$

The conflict depicted here prefigured the ensuing crisis that Verhaeren underwent for three years, a period of illness, both physical and psychological. He chronicled his descent in a set of poetic works, the Trilogies noires (1888-91). Here, searing self-scrutiny and relentless suffering are depicted, conveyed in images of a world contracting to "icy coldness," wrapped in "chains," "howling dogs," and "frozen midnights," devoid of sun. Verhaeren's move from pain and torpor to vitality and energy was made possible by a confluence of love in his life and turbulence in his political context.

In 1891, Verhaeren married, and he began a decade of wide-ranging social engagement and prodigious creative output. A series of mass uprisings by industrial workers roiled Belgium in 1886. These waves of unrest by miners, glassworkers, steel mill and textile workers, among the lowest-paid and most brutalized of Europe, led to the creation of the Belgian Workers' Party (Parti ouvrier belge, or POB). While a juggernaut of advanced industrialism, fierce resistance to state intervention and an extreme "Manchesterite" liberalism dominated 188 os Belgium, preventing consideration of even the most rudimentary labor laws that protected workers in other countries, from the regulation of children's and women's work to a curb of the fourteen-hour day. And until 1894, political rule in Belgium was based on an electorate restricted to less than 4 percent of the population. The eruption of working-class radicalism galvanized Verhaeren, Picard, and the unitary avant-garde to embrace the goal of political reform and universal suffrage.

Fervently committed to the POB, Verhaeren joined socialist Émile Vandervelde to found the Section d'art of the Brussels Maison du peuple (People's House), a multifaceted cultural education program for workers. His social activism also spurred the radicalization of his artistic production. ${ }^{20}$ After 1893, Verhaeren invented a new poetic variant of symbolist free verse, transposing the elusive contortions of Mallarmé's dream states into the titanic blasts of Belgian machine shops and industrial cities. In so doing, he reimagined modernity and the boundaries of bourgeois life in ways fundamentally different from the artists examined by Seigel: Verhaeren's poetry represented an unprecedented world as formidable, and tormented, destined to explode in revolution and subsequent universal liberation. He encompassed the contours of this world in new subjects and with distinctive expressive techniques.

19 Émile Verhaeren, Contes de minuit, contes gras, frontispiece by Théo van Rhysselberghe (Brussels, 1884), 5-19.

20 Paul Aron, Les écrivains belges et le socialisme (1880-1913) (Brussels, 1985), 25-125; 253-66. 


\section{THE TENTACULAR CITY: VERHAEREN'S SOCIAL VISION}

In his early works, Verhaeren captured the extremes of carnality and piety, and for a time he was suspended between them. His mature social vision pitted the confrontation of country and city. The first of his series of politicized works, Les campagnes hallucinées (1893) evokes the desolation and depopulation of the countryside; its uprooted inhabitants, "as though they were hallucinated," are drawn irresistibly to the city. To Verhaeren, the countryside is "haggard, exhausted," "sucked dry" by the city-the "form of the future." He portrays the city, an industrial city, in an arresting image: as an insatiable, tentacular octopus, extending its many arms to lap over, latch on, and "drain the life's blood of the country." ${ }^{21}$ The restless dynamism of Verhaeren's city operates in reverse direction from the modern experience cast by Seigel and Simmel. Theirs links and opens out to new fields of connection, densely threaded. His tentacular city forms what he calls "a squeezed" and "tangled knot of wills";22 it draws all in, destroying as it fortifies, a matter of concentration and domination.

The full force of Verhaeren's social and literary vision emerges in Les villes tentaculaires (1895). The range of subjects broke the mold for poetic rendering. They comprise a microcosm: of the masses, classes, processes, and institutions convulsing the modern industrial city. Docks, railway stations, steamships, and shop floors appear in the repertoire. The factories of "Les usines" swarm with battered workers where blasting smoke, steam, and fiery furnaces envelop them and run interminably, "day and night." Steel, coal, coke, and engines are forged here while mechanical looms roll out cloth in a deafening clatter of an automatic tictaquement. These poems bear little resemblance to previous artists' attempts at expressive forms of modern technology, and they have no parallel among European avant-garde contemporaries. Verhaeren cast no "iron lilies of the Strand," 23 but presented "the pulsation of machines" and "the slow rise of the masses" that worked them. He is credited with being "the first poet to see ... the grandeur of mechanical invention," "the superb epic which is modern industrialism." 24

At the heart of Verhaeren's visionary tentacularism is capital and the bourgeoisie, and one poem sets a monument to the bourgeois-masterful,

${ }^{21}$ Émile Verhaeren, "La ville," in Verhaeren, Les campagnes hallucinées: Les villes tentaculaires, ed. Maurice Piron (Paris, 1982), 24.

22 O. F. Theis, "Émile Verhaeren," North American Review 198/694 (1913), 354-64, at 360.

23 Richard Le Gallienne, "Ballad of London," in Le Gallienne, Robert Louis Stevenson: An Elegy and Other Poems (London and Boston, 1895), 26.

24 Lowell, "Émile Verhaeren"; see also the Belgian socialist newspaper Le peuple, 24 Nov. 1926, quoted in Eugenia W. Herbert, The Artist and Social Reform, France and Belgium, 1885-1898 (New Haven, 1961), 139. 
rapacious, creative, and callous. Throughout the volume Verhaeren conveys the city as a living being, monstrous and marvelous, surging and seething, a colossal manifestation of the human power that created it. If few artistic precedents are traceable, the tone and themes of Verhaeren's 1895 work correspond most closely to Marx's early writings, which celebrate the heroic achievements of the bourgeoisie, whose unleashing of energies and resources propels a thoroughgoing transformation of the world and the ever-greater clarity of class conflict. The laborers in Verhaeren's industrial cities endure what he calls "active misery," and one poem, "La révolte," presents a short-term uprising. With more time and intensified production, Verhaeren, like Marx, believed crisis and apocalyptic redemption would inevitably yield a new world; the future was bound to explode in revolution and a community of equality in its aftermath. ${ }^{25}$

Les villes tentaculaires drew its raw materials from the Belgian powerhouse of advanced industrial production that flourished during the last two decades of the nineteenth century and deepened through 1910. In this way, Verhaeren's poetic spectacle dramatized elements distinctive to his national context, where historians locate a particular concentration of the Second Industrial Revolution. Verhaeren's radical social vision realized, in literary form, the liberation and transformation that Marx had identified decades earlier. It was decidedly fitting that Marx's ideas resonated in Verhaeren's poetry, as it was in Belgium, and in a Brussels café, that Marx had first articulated the inexorable confrontation of industrial labor and bourgeois masters; it was there, in exile, that he had written The Communist Manifesto.

Whatever his affinity with Marx, the most significant innovations of Verhaeren's modernist poetry were his disruptions of literary form. These clustered around Verhaeren's use of "free verse" — vers libre - which rejected the constraints of the classical alexandrine, injecting irregular rhythms rather than patterns of rhyme to shape the stanzas. Verhaeren adapted free verse from the stylistic breakthroughs of three 188 os French symbolist poets who are central to Seigel's Bohemia: Mallarmé, Verlaine, and Rimbaud. Verhaeren visited and befriended Mallarmé and Verlaine in Paris, revered them, and studied their work; he and Picard were among those who invited Verlaine to a lecture tour in Belgium in $1893 .{ }^{26}$ But Verhaeren boldly refashioned symbolist free verse to fit the unprecedented upheavals of industrial modernity and social revolution he aimed to capture, radically reversing the aims of the French poets who inspired him and demonstrating, once again, the divergence between the Belgian and French avant-gardes. French symbolists shifted from outer to inner reality as

25 Émile Verhaeren, "La révolte," in Verhaeren, Les campagnes hallucinées: Les villes tentaculaires, 135-8, at 135; "Vers le futur," in ibid., 156-8, at 156, 157.

26 Gustave Vanwelkenhuyzen, Paul Verlaine en Belgique (Brussels, 1945). 
the source of meaning and value; they pressed the new poetic free verse into the service of externalizing the dream. Verhaeren's symbolism sought to embody the dream made real, the hyper-reality or "hallucinatory real" of the chaotic industrial colossus sweeping through his external world.

\section{THE ART OF CREATIVE DESTRUCTION: VERHAEREN'S SYMBOLIST POETRY}

Three elements of the symbolists' credo provided the foundation for Verhaeren's distinctive stylistic techniques. All three are central to Seigel's interpretation of modernism as free subjectivity and aspiration for boundarylessness, but Verhaeren's vehement transformation of them illustrates another type of bourgeois creativity, at the cusp of abstraction.

First, Mallarmé invented free verse, liberating sign from referent and verse structure from rhyme. Poems must "suggest, not describe," he noted, approaching an ideal world beneath the surface of appearances, the evocative forms of an indefinable, indeterminate realm of metaphysical mystery. Expressing the inexpressible in Mallarmé's free verse meant reduction and repletion: fewer words, rife with indefinite, multiple, and allusive qualities. Verhaeren's second mentor, Verlaine, deepened the links between poetry and music, the fusion of verse and sound, which had inspired Mallarmé's admiration of Wagner and the ideal of the unity of all the arts. Verlaine's symbolism glorified the flowing non-specificity of music and words as musical notes, as images detached from the ground of literal description. Finally, Verhaeren venerated Rimbaud, the memorable character from Bohemian Paris, who defined the poet's quest for a "vision beyond the ordinary limits of personal existence" $(B P, 262)$, a plumbing of the depths by the "dérègelement des sens" ("the disordering of all the senses") and (like Verlaine) "the dissolution of moral and material boundaries" (BP, 253). In this descent into the self and commingling of "perfumes, sounds, color, and thought" Rimbaud etched his symbolist Illuminations (1886), seeking out an elemental and "universal language of the soul." ${ }^{27}$

Verhaeren's visionary tentacularism mobilized free verse and the stylistic lessons of French subjectivist symbolism to unique and provocative ends: to activate Belgian social change through literary form. His verse structure, images, and technical procedures sought to render the heft, density, restlessness, and supple relentlessness of industrialization and the masses and elites who propelled it forward. Here it was not the Rimbaudian disordering of the senses and the self that shaped the poet's task, but the deregulation or disordering of the outer

27 Rimbaud quoted in Edmund Wilson, Axel's Castle: A Study of the Imaginative Literature of 1870-1930 (New York, 1959; first published 1931), 216. 
world that galvanized his creative attention. Verhaeren's encounter with that world yielded a new language, what his friend and fellow writer called in 1905 his astonishing dérèglement lexicologique, a wild disordering of the word. ${ }^{28}$

Let me briefly contrast Verhaeren's symbolist style to the figures Seigel considers. First, free verse, Mallarmé's principal innovation, became in Verhaeren's hands what his contemporaries characterized as a "violent" and "volcanic" cutting loose. His stanzas, in irregular rhyme, were "divided into parts" and "so long as not properly to be considered stanzas at all." More than twenty lines, for example, formed a section of "Les usines" (The Factories). "Elongated," "bulging," and "swollen" were typical terms used to describe Verhaeren's poetic structure. Mallarmé's free verse broke the barrier of the classical alexandrine in the service of distillation and reduction: minimal words for maximum meaning and the allusive mystery of the ineffable. Verhaeren's free verse stretched the stanzaic boundaries to bursting: overloaded, and overflowing, multiplying and piling on cascades of words suited to the surging external world he sought to represent. Before Verhaeren adopted free verse, as in the debut volume of Les flamandes, critics noted the tension between form and content: Stefan Zweig commented that Verhaeren's early style maintained the conventional stanza form but, as Zweig put it, "wild stallions were still trotting along in the harness of the alexandrine." ${ }^{29}$ Set free and unbridled, Verhaeren's modernist symbolism shattered poetic precedent. His verses' pace, packed pulse, and jolting force led his admirer and mentor, the Belgian writer Camille Lemonnier, to compare them to the physical assault of bands of brigands against the Roman Empire (called the baugaudae): as insurgents had smashed the walls of elite enclosures, Verhaeren's "brusque cadences" and wild style formed literary violence "sacking tradition." 30

Second, Verhaeren mobilized the linking of music and poetry, the fusion of verse and sound that Verlaine hailed as a hallmark of symbolism, to utterly different ends. He replaced the delicate melody of French modernist subjectivism with the percussive clamor of Belgian modernist tentacularism. For Verlaine and his coterie, the musicality of poetry was inextricably tied to its capacity to spark synesthesia, the interrelation of all the senses; theirs was a symbolist sensorium of dematerialization. Verhaeren, by contrast, designed his variant of free verse as a synesthesia of urban industrialization, materialized in literary form. A dream state of floating meditativeness commingled all the senses for Verlaine and Mallarmé.

28 Camille Lemonnier, "La vie belge," in Paul Gorceix, ed., La Belgique fin de siècle (Brussels, 1997), 69-201, at 138.

29 Quoted in Selected Poems: Émile Verhaeren, ed. and trans. Will Stone (Todmorden, 2014), introduction, n. p., Section II.

30 Lemonnier, "La vie belge," 138. The bagaudae were third- and fourth-century rural rebel bands that attacked the Romans. 
Verhaeren's symbolist socialism assaulted all of the senses, evoking the oppressive physicality of the modern industrial city and inducing it for the reader in ways close to corporeal conditions.

He achieves this urban industrial synesthesia through a number of methods: graphically visual images, startling metaphors, frequent onomatopoeia, and word choices abounding with rough, guttural sounds. Here are a few examples culled from the poems "La ville," "La révolte," "Le bazar," "L’âme de la ville," "La bourse" and "Les usines." Soundscapes intrude, emitting a constant racket (Verhaeren's recurring word is vacarme, and he also turns it into an adjective, vacarmant (sic)). Verhaeren's verbs activate the noisy tumult: furnaces blast and engines roar (gronder, hurler, ronfler); street crowds grumble, nearly chanting (scander); "steely hammers" pound and crack on metal and wood; cranes groan and snap; laborers en route to work pant and gnash their teeth (haleter, grincer); trains rumble below ground then clatter and screech as they emerge to station.

Amidst the din, Verhaeren summons all the other senses to agitation. They commingle in ways that amount to what I would call paroxysmal synesthesia, adapting the word that literary critics of his time and after used to describe Verhaeren's style as a whole. In the poems of Les villes tentaculaires, light blazes night and day, and all eyes strain to encompass the colossal sprawl of the industrial cityscape. Workers' eyes smart and fill with tears from smoke, steam, and coal dust. Throats parch on the factory floor, and mouths foam with money lust at the Stock Exchange. Fumes pour out, and skin burns and hardens within the rolling mills and metal shops. Dockers' loads press their backs and shoulders. Street crowds push and jostle, as they swarm, a "tumult," evoked by Verhaeren with terms like cohues, se bousculent and fourmillant. ${ }^{31}$ The somatic pressure and friction on all the senses, interacting, form a very different register from those in the world of Mallarmé and Verlaine. A frisson of soft brushing of a deer's downy fleece arises in "L'après-midi d'un faune"; in Verlaine's "L'art poétique" (1884) the poet's appeal to "music, ever and always," yields a soul "taking flight" skyward where "mint and thyme" waft through the celestial air. Grit and sweat permeate Verhaeren's grounded field, where the musicality of poetry stirs cacophony, discomfort, and disruption.

Crowds on urban streets as the site and source of modernity bring Verhaeren closest to and distinct from his much-admired predecessor, Baudelaire, the pivotal figure in Seigel's analysis of the avant-garde and the boundaries of bourgeois life. Baudelaire's metropolis and mental life are set in Haussmann's Paris, the new nineteenth-century capital of leisure and pleasure. Here, as we have seen, the artist

31 Émile Verhaeren, "L'âme de la ville," in Verhaeren, Les campagnes hallucinées: Les villes tentaculaires, 91-5 ; Verhaeren, "Les usines," in ibid., 120-22 ; and Verhaeren, "Le bazar," in ibid., 127-9. 
takes "a bath of multitude,"32 reveling in the expansion of ego and sensibility; absorbing and refracting all the energy on the boulevard, the writer becomes the "kaleidoscope endowed with consciousness" (quoted in $B P$, 114). He then pulls back, distilling the "weird pageant" of life through the discipline of art. ${ }^{33}$ Baudelaire's artist as man of the crowd joins his artist as the dandy, who sets himself apart, blasé and detached. He suppresses all emotion, adhering to a rigorous code of laws created for the self, and creating the self as a work of art.

The tentacular cities of Verhaeren's fin de siècle Belgium offer no spectacle of pleasure and leisure, but form powerhouses of production and domination. In the Parisian urban scene, Baudelaire's poet accepts a condition of creative isolation. Verhaeren as symbolist socialist embraces the poet's role as creative exhortation. Where the dandy is blasé and detached, Verhaeren's poet is impassioned and inflamed, deeply identified with the suffering of workers and outraged by the iniquities of capital. Rather than a "kaleidoscope endowed with consciousness," he is an insurgent, an agent provocateur of class consciousness through art. As Seigel suggests, Baudelaire's personal ethic and stringent discipline were required to inscribe the boundaries of a self rejected by a hostile world, impervious to change. Verhaeren, notoriously distinguished for his vehement, "stormy" and undisciplined literary style, wielded his art to rouse to action and radically overturn the world. What commentators called his "vers... enragés" formed poetic equivalents to the uprisings of the oppressed that he saw around him and hoped to amplify to full-scale revolution and a new society. ${ }^{34}$

The third and final divergence between Verhaeren and the French symbolists who inspired him coheres at the level of word usage: his deformation and "deregulation of language." We recall Rimbaud's disordering and hallucinatory interiority, accompanied by the breaking apart of language, stripped down to its component parts-what the young poet called pure "perfumes, sounds, colors" that might yield an essential "universal language" for "a universal soul." 35 Verhaeren cherished Rimbaud, but his own form-breaking symbolist technique centered not on breaking down but on building up and, indeed, overloading poetic language. As we have seen, Verhaeren adapted the radicalism of free verse from Mallarmé, but he replaced the French symbolist's economy with exorbitance: his rhythmic stanzas were stretched and lengthened to bulging. So, too, were the bulky words Verhaeren chose to set within them. All literary critics, past and present, note a signature feature of Verhaeren's style and his singular elocution: his invention of new words, an insistent vocabulary of neologisms.

32 Charles Baudelaire, "Crowds," in Baudelaire, Paris Spleen, 20.

33 Baudelaire, "The Painter of Modern Life," 402.

34 Lemonnier, "La vie belge," 138.

35 Quoted in Wilson, Axel's Castle, 216. 
One commentator called it "La rage des mots nouveaux" ("A rage for new words"). They included, for example, molassement, fourmilleusement, recordée, émerauder, s'empanacher, attristement, rauquer, se mesquiniser, torpidement, larmer, enturquoiser, lamenatables lamentos, and scores of others. Verhaeren's frequent reliance on pleonasms piled on to the neologisms and the unusually long stanzas to convey a sense of Verhaeren's poems as sprawling and overfilled; some writers denigrated them as unwieldy, vexatious, and even exhausting for the reader. ${ }^{36}$

Verhaeren pursued his deformations of vocabulary and stanzaic excesses as strategies of belgitude, demonstrating a final disparity with Seigel's trio of avant-garde French symbolists. New studies of the poet indicate how he relished departures from linguistic propriety in order to "delatinize French" and to inject Flemish sounds and word types into his modern poetry. ${ }^{37}$ While well schooled at Saint-Barbe and after in the rigors of Parnassian classicism, Verhaeren took every liberty possible in his variant of symbolism to evoke the rough, coarse and guttural sounds of Flemish as well as to invent Flemish versions of French words; he considered these "muscular" and forceful, while others deemed them "savage" and "barbarous." These terms he found appealing and acceptable as descriptions of his literary project.

One poem in Les villes tentaculaires, "La Bourse" (The Stock Exchange) encapsulates many of the distinctive qualities of Verhaeren's symbolist socialism. It also crystallizes what I see as key elements of Marx, Simmel, and Seigel that can be illuminated by Verhaeren; the poem brings me back to them in a new way. Throughout Les villes, as we have seen, Verhaeren dramatizes the dynamism, energy, and oppressive crush of the colossal constructed environment created by men and machines, and its ultimate transformation by social revolution. In "La bourse," Verhaeren evokes the theme of creative destruction by isolating the driving force underlying the totality of the tentacular world he depicts: money. The poem emphasizes what might be the predictable features of the money economy of capitalism - its fluidity, volatility, and instability. But Verhaeren's language and images are set in another register-he shows gold bars, bank notes, and the stock market itself as sites of derangement. Maniacal emotions govern the

36 Camille Hanlet, Les écrivains belges contemporains de la langue française, 1800-1946 (Liège, 1946), 186-7; Maurice Piron, "Préface," in Verhaeren, Les campagnes hallucinées: Les villes tentaculaires, $7-16$, at 15 .

37 Patrick McGuinness, "Preface," in Verhaeren, Selected Poems, i-iv, at ii, iv. This tactic was first tried by Charles de Coster, who invented Flemish-sounding French words and antiquated them to seem as if from the sixteenth century. See Debora Silverman, "Art Nouveau, Art of Darkness: African Lineages of Belgian Modernism, Part III," West 86th: A Journal of Decorative Arts, Design History, and Material Culture 20/1 (2013), 3-61, at 24-6, $51-2$. 
realm of "La Bourse," generated by two conditions: insatiable lust for fortune, and chasing after an invisible phantasm. The poem takes up the fundamental character of money as an abstraction, presented here not as a fetishism of the commodity as Marx defined it, but as the fetishism of money itself as an immaterial fantasy. Indeed, the poem could be summarized as a variation on Marx's "all that is solid melts into air." Marx's statement was made in awe of bourgeois capacities for relentless production. Verhaeren's poem explores the pathology of money as air itself.

Just a few examples convey the remarkable tone. The poem begins and ends likening the bourse to a distant monument of gold shrouded in the shadows ("dans les ténèbres"). Inside, daily battles of "terror," "fear," and "monstrous" hope take place in this "mad palace." More than the "ardor" of love and the "fervor" of faith, Verhaeren writes, "la rage de l'or" (the rage for gold) is accompanied by burning fever and fury, though this wild pursuit of riches is but a cruel game of chance, built on panic, and delusion. Images of vaporization and the power of the "chimera" appear throughout the long poem; toward the end, Verhaeren writes a compelling stanza representing money as multiple mirages, stacked on shelves, while beseeching millions, arms outstretched, pray to them. ${ }^{38}$

Verhaeren's vision of the ever-elusive conjury of money approaches, in poetic form, Marx's post-1848 realization, in Seigel's account, that the veil of illusion might never be stripped away to reveal the clear truth of the substructure of capital and class conflict. Verhaeren's "La bourse" is also uncannily close to Simmel, and to the Simmel different in tenor from the thinker inspiring the ideas of the extending links and thickening threads of Seigel's network of means. In Simmel's "The Metropolis and Mental Life" a dark side of money appears, which bears some affinity with Marx's "cash nexus," but goes further, and in a more psychological direction, like Verhaeren's. Simmel writes of the money economy that it "hollows out the core of things"; the metropolitan citizen lives where "all things float with equal ... gravity in the constantly moving stream of money." 39 Verhaeren captured this quality ten years earlier, and in Belgian industrial cities. He represents money as "a strange new blood" that "seems to flow in the veins of the multitude" as it forms "the beating heart of the world." These money hearts he calls not a stream constantly moving, but an "ocean," "a tangled knot of wills." 40

38 Émile Verhaeren, "La bourse," in Les Campagnes hallucinées. Les Villes tentaculaires, 123-6, at 125 .

39 Simmel, "The Metropolis and Mental Life," 330.

40 Émile Verhaeren, quoted in Theis, "Émile Verhaeren," 360; Verhaeren, "La bourse"; Verhaeren, "L'âme de la ville," in Verhaeren, Les Campagnes hallucinées: Les villes tentaculaires, 93 . 


\section{VERHAEREN'S IMPERIAL MODERNISM}

For Verhaeren, the ocean-tangling wills driving capitalism would be replaced by a lifeblood of vital harmony once revolution inexorably erupted. But the ocean and its surging waves dominate a second thematic pattern in Verhaeren's oeuvre and his quest for belgitude: the thrill of empire. At the height of his creative powers, Verhaeren combined socialist aspiration with imperial affirmation. Collectivist hope shaped his poetry of free-verse choruses to men, machines, and insurgency; King Leopold II's "acquisition" of the Congo Free State (18851908) stimulated Verhaeren's enthusiasm for Belgian overseas expansionism. This anomalous "colony without a metropole," a fictional state of about 20 million people owned by the king, ruled by decree, and run from Brussels came to seize hold of many in Belgium, Verhaeren among them. They rallied to it as a form of national vindication: they believed in part that their small, new, and neutral nation had been summoned as liberators and masters of one-thirteenth of the African continent, outmaneuvering the Great Powers who had earlier carved up the map and dictated the tight squeeze of Belgium's own borders and had relegated its military to a state of perpetual dependence on outsiders to guarantee its territorial integrity.

Simmel's wave and Seigel's social tools roll out, forging interdependence and distant connections. Verhaeren's waves roar in, bursting with faraway treasures extracted. Unexamined traces of imperial enthrallment converge with, and complicate, Verhaeren's symbolist innovations and political engagement. The form-breaking language of free verse, as we have seen, strove to meld the artist's subjectivity with the social, spurred by identification with labor. But Verhaeren's free-verse symbolism also inhered in what I call a particular form of imperial modernism. Here the boundarylessness sought by the bourgeois artist embraced a disruption of national borders, carrying with it a reordering of self, society, and violence that the conjury of the Congo belge set off.

I cannot here discuss fully the contours of Verhaeren's imperial imaginary; I do that for other purposes in other publications.$^{41}$ Here I offer, in conclusion, two examples from a haunting repertoire of images of hands in Verhaeren's symbolist poetry of 1895 and 1902. These direct me to a final reflection on a type of avantgarde modernity and the boundaries of bourgeois life that differ from and amplify Seigel's magisterial analysis that focuses on Western Europe and leaves out liberal and imperial Belgium.

Among the ranks of modern heroes in Verhaeren's poetry are colons and imperial "adventurers." The radical vision of Verhaeren's urban "tentacularism" encompasses an imperial centerpiece—the tumultuous seaport. "Le port" (1895),

${ }^{41} \quad$ Silverman, “Modernité Sans Frontières," 781-6 n. 14. 
inspired directly by the artist's native Antwerp during the first decade of Belgian expansionism in Africa, is rendered as a propulsive launch and an irresistible lure of overseas bounty. In Les villes tentaculaires, the city as factory absorbs the country, while the city as port ensnares the world.

Verhaeren's Antwerp was indeed a tentacular port at 1895, and the poet witnessed the city's rapid emergence as a global imperial hub. The urban population had tripled between 1850 and 1900, doubling from 1880 to 1900. Massive construction sites along the harbor assembled a series of new docks, wharves, and warehouses to accommodate accelerated expansion of international trade, with a special site, the 1887 Afrikadok, for Congo steamers. By 1897, Antwerp was the largest ivory market in the world, and the commotion of the harbor city encompassed a workforce of more than 25,000 at the quais. ${ }^{42}$ Haussmann's demolition and redevelopment of Paris gave the French symbolists a capital of luxury, sociability, and cénacles; Antwerp's swift modernization yielded a juggernaut of transatlantic trade and the nucleus of Belgium's imperium.

In Les villes tentaculaires, "Le port" evokes this astonishingly vitalized Antwerp. Verhaeren vivifies the harbor's unusual sights and sounds, describing a clamorous and hulking maze of cables, poles, sails, and cranes, "swarmed" by men who heave, sweat, and haul, and filled with steamers, smoke, and roaring engines. Verhaeren's "Le Port" imagines the resurgent "city" grasping, "as a hand, its fingers open, closing over the whole world." 43

In a later collection called Les forces tumultueuses (Tumultuous Forces) (1902), the sea and the city are featured anew as the convulsive sites driving men's insatiable quest to penetrate and master the universe. A central poem in the volume, "La conquête" (Conquest), captured what Verhaeren presents as the dynamism, audacity, and energy of the dual forces goading overseas expansionism: acquisitiveness - the lure of wealth—and inquisitiveness- the lure of the unknown. Verhaeren's rhythmic pulse and uneven rhyme activate the verses where imposing ships speed off for distant horizons, their sails swelled and lashed by whipping winds and guided by formidable men of initiative and daring bound for the infinite. At the end of the poem, Verhaeren places an arresting image of a hand at the port: a giant hand with multiple, knotted fingers, opening and closing in a fist. The giant hand as fist at the harbor, opening in

42 "Antwerp," census figures from the 1911 Encyclopedia Britannica, online version; Edmond de Bruyn, "Anvers," Notre pays, 1 (1905), 245-76; Wilfred C. Robinson, Antwerp: An Historical Sketch (London, 1904), 278-80; Herman Wauters, De Semini-saga (Brasschaat, 2010), 51-60; Lt. Th. Masui, Guide de l'état indépendant du Congo à l'Exposition de BruxellesTervueren en 1897 (Brussels, 1897), 330-31; Silverman, "Art Nouveau, Art of Darkness, Part III," 26-30.

43 Émile Verhaeren, "Le port," in Gorceix, Fin de siècle et symbolisme, 246-8, at 247. 
torsion and tightly clenching, draws to it extensive transit lines ("wakes") traced by innumerable ships; it resembles, in Verhaeren's rendering, a global nerve bundle that contracts the fingers of this totalizing hand:

And the clear wakes that, from port to port

Bright ships trace ... through the seas,

Would seem the great, global bundle of nerves

That contracts the fingers of this enormous hand. ${ }^{44}$

The myriad lines of ocean vessels compose "a network of means," Belgianstyle, with linkages and fields of connections different from the Simmelian ones that Seigel mobilizes for his study. Seigel's European modernity clusters as threads that grow thicker, densely massing-like Simmel's single spun piece, endlessly growing more. Verhaeren's dynamic modernity propels hands that reach out, grasp, and grip, ever more tightly. In his imperial Antwerp of the 189os, Verhaeren reclaimed the port, surging with steamers, as a giant outstretched hand, all fingers splayed and taut, tensing up and reaching out. The drive to expansionism unfolds knowledge of the unknown, Verhaeren concludes, but also unleashes unbounded voracity-what he calls in another poem "les cerveaux voraces" of "ma race" "the voracious minds" of "my race"). 45 The boundaries of the buffer nation burst open, with a giant hand pulling all in; the world was up for grabs for little Belgium, and there for the taking.

\section{CONCLUSION}

Jerrold Seigel transformed post-French Revolutionary European history by identifying the paradox of free subjectivity and the boundary problem that would forever accompany it: how to draw the lines of limits to self-mastery and self-development in societies let loose from the prescribed location, and fierce constraints, of ancien régime corporate hierarchies? Seigel's insights are simultaneously social and depth-psychological, and continue to frame our inquiries about the nature of bourgeois identity in varying national circumstances.

Simmel, with whom we began, offers a fitting conclusion, resonant with the range and depth of Seigel's explorations:

individual thinking ... moves from multiplicity to unity and from unity to multiplicity. The history of thought shows that it is vain to consider any one of these viewpoints as definitive ... People are not divided into categories by the contrast between differentiation and unification of their life experiences. This contrast exists in every individual, although

44 Émile Verhaeren, "La conquête," in Gorceix, Fin de siècle et symbolisme, 280-82.
45 Émile Verhaeren, "Ma race," in Gorceix, Fin de siècle et symbolisme, 285-6. 
his inner personal form evolves in interaction with his social form, which moves between individualization and socialization. The essential point is not that these two trends constitute life, but that they are interdependent in a heuristic form. It seems as if our life employs or consists of a unified basic function that we are unable to grasp. We have to dissect it by analysis and synthesis, which constitutes the most general form of that contradistinction, and whose cooperation then restores the unity of life. ${ }^{46}$

Seigel's rich and generative books exemplify the interdependence of unity and multiplicity, individualization and socialization, that Simmel proposes as an imperative "heuristic form." Mobilizing his great gifts for analysis and synthesis, Seigel invests that interdependence with remarkable historical density, providing us with incomparable guides to the complexities of modern life. 